\title{
20. INTERSTITIAL WATER STUDIES ON SMALL CORE SAMPLES, DEEP SEA DRILLING PROJECT, LEG $1^{1}$
}

\author{
F. T. Manheim² , U. S. Geological Survey, Woods Hole, Mass. \\ and \\ F. L. Sayles, Woods Hole Oceanographic Institution, Woods Hole, Mass. \\ With deuterium determinations by Irving Friedman ${ }^{2}$, U. S. Geological Survey, Denver, Colorado
}

\begin{abstract}
The most dramatic variations in pore water composition occurred in Holes 2 and 3 in the Gulf of Mexico. Both holes showed a strong increase in salinity with depth, evidently owing to diffusion from underlying salt bodies. However, on Challenger Knoll (Hole 2), a sharp drop in salinity was observed in the cap rock of the salt dome, in which chloride fell to only $4.8 \%$. The drop is attributed to production of fresh water during the formation of native sulfur.

Outside of the Gulf of Mexico, changes in total salinity with depth did not exceed a few per cent, but differences in diagenetic modification of the ionic ratios of sea water were pronounced. In nondiapiric strata in the Gulf of Mexico (Hole 1) both magnesium and potassium were depleted in the pore waters, whereas in the open ocean holes $(4,5,6$, and 7 ), potassium appeared in excess. Water content (porosity) of the cores was irregular.
\end{abstract}

\section{METHODS}

Major constituents were determined on small pieces of core, taken from the centers of samples recovered on Leg 1 . The samples were carefully preserved, as described in the Core Manual, in 2-ounce screw-capped (Polyseal) jars, squeezed in a stainless steel squeezer (Manheim, 1966) in the Woods Hole Laboratory, and divided into aliquots for various operations. Total available effluent ranged from less than 1 milliliter to about 3 milliliters, excluding water that was squeezed and filtered aboard ship, and fused in polyethylene tubes. These were reserved for future work. Additional aliquots, squeezed in our laboratory, were fused in glass ampules and sent to Irving Friedman for deuterium analyses.

Additional core samples were supplied from the cap rock found in Hole 2. These samples had been frozen for hydrocarbon analysis and the central portions of two pieces of core were removed and shipped here. Although the topmost core was heavily permeated with oil, it produced chiefly saline water, with only a surface film of oil when squeezed at pressures up to $2,300 \mathrm{~kg} / \mathrm{cm}^{2}(35,000 \mathrm{psi})$.

Large samples intended for trace-metal analysis were obtained for I. R. Kaplan and his colleagues at University of California, Los Angeles, whose results

\footnotetext{
${ }_{2}^{1}$ Woods Hole Oceanographic Institution Contribution No. 2206.

${ }^{2}$ Publication approved by the Director, U.S. Geological Survey.
}

are reported concurrently (Kaplan and Presley, Chapter 21). Samples squeezed on board ship were placed in special containers for oxygen isotope study. Results of these studies will be repórted later by W. G. Deuser of the Woods Hole Oceanographic Institution.

Chloride was determined by microtitration with standard Mohr reagents, using a weight burette. Sulfate was determined microgravimetrically by a modification of the method of Shishkina (1954). Sodium and potassium were determined by atomic absorption spectrophotometry; magnesium and calcium were determined by both atomic absorption and emission spectrometry (solution spark), and strontium, manganese, boron and lithium were analyzed by emission spectrometry. Water content was determined by heating the fresh sediment at $110^{\circ}$ to $120^{\circ}$ overnight and recording weight loss. Details of methods are in preparation.

Refractive index was determined by using a temperaturecompensated hand refractometer (A/O Spencer) on a drop of pore fluid, squeezed from samples both on board ship and at the laboratory. These indices are reproducible to about $0.5 \%$ total salinity, and were converted to salinity units according to the relationships reported for sea water (Behrens, 1965, and Mehu and Johannin-Gilles, 1968). The assumed relationship does not hold strictly for ionic ratios differing from those in sea water, but the results are frequently rather close to the analyzed total salinities (Table 1) and are useful as a quick preliminary classification especially for shipboard work) of the nature of the pore water. 
Standard errors (i.e., reproducibility) for the chemical constituents in the small samples presently under study are: sodium, 0.3; potassium, 0.02; calcium, 0.03 ; magnesium, 0.02 ; chloride, 0.1 ; sulfate, 0.03 . Values in Table 1 are the mean of at least two analyses. The analyses do not meet accuracy standards for open ocean waters, but are designed to reveal the larger chemical variations expected in deep pore fluids. They are believed to be free of systematic errors appreciably outside the range of standard error (and implied by the rounding of results) and outside the artificial variations introduced by handling and sampling the core materials by the various scientific team members working on board ship and in the laboratory. These errors do not, however, include occasional gross errors and mishaps. Because of the limited quantities of analytical material available, gross errors were sometimes irreparable. Cation-anion balance was calculated by converting the values in Table 1 to equivalents. The usual excess of cations was attributed largely to bicarbonate alkalinity, and so calculated in the table. A sum or total salinity was then computed. Because of the scatter in the reproducibility of the major constituents, the calculated bicarbonate was only a rough figure, giving approximate ranges of values. Values in the range -0.1 to $0.3 \%$ merely indicated adequate balance of the major constituents and a low bicarbonate alkalinity such as is found in open ocean waters (about $0.15 \%$ ).

\section{RESULTS}

\section{General Comment}

All analyses of major inorganic constituents on samples received by us are recorded in Table 1 . For Holes 2 and 3, which displayed large variation in total salinity, the chlorinity data of the UCLA group were combined with this group's data and plotted on Figure 1. Results of shipboard refractometer readings, converted to approximate chlorinities on the basis of the relationships between refractive index and chlorinity found in Hole 3, are also plotted.

\section{Hole 1 (Sigsbee Scarp)}

Chlorinity and total salinity show a small but significant increase with depth. The main noteworthy feature is the depletion of potassium (by nearly 40 per cent with respect to sea water) in the sediments, in contrast with the excesses found in the open oceanic holes. Magnesium, as in most of the samples, is depleted with respect to sea water. The intermediate sample retains a surprising amount of sulfate, compared with previous samples of pore water studied from the northern Gulf of Mexico (Manheim and Bischoff, 1969), since sulfate reduction is known to be an active process in Gulf sediments generally.

\section{Hole 2 (Challenger Knoll)}

This hole, which penetrated the oil-soaked cap rock of a salt diapir, displays a sharp increase in chlorinity and salinity with depth, yet does not reach the nearsaturation levels for sodium chloride found in similar holes on diapiric features in the northern Gulf of Mexico (Manheim and Bischoff, 1969). The dramatic decline in salinity and chlorinity to brackish levels $(4.8 \%$ \% $\mathrm{Cl})$ within the cap rock itself may provide the answer to this anomaly. The fresh water influence cannot be ascribed to external contamination such as drilling fluid, for no fresh water mud was used in drilling this hole until all coring operations had been completed (David Wirth, Scripps Institution of Oceanography, personal communication). Therefore, a source of fresh water in the vicinity of the salt plug itself is involved. Such sources may arise from the oxidation of petroleum hydrocarbons, utilizing oxygen from sulfate (via sulfate-reducing bacteria) and the decomposition of hydrated calcium sulfate (gypsum). These processes and their significance will be commented on in work in preparation.

One may further note that the brackish water is high in calcium and sulfate, as one might expect from the solution of gypsum, and low in magnesium and potassium. To judge from the composition of the cap rock fluid, as well as that of higher-level pore waters reported by the UCLA group, no significant amounts of late stage evaporites containing unusual quantities of magnesium, bromide, and potassium are present in the Challenger Knoll salt mass. Otherwise, these constituents would have tended to diffuse upward and outward and enrich the pore waters.

\section{Hole 3 (Abyssal Plain)}

The major feature in this hole is its strong and characteristic increase of salinity with depth. Although the hole is several tens of kilometers removed from any known diapiric features, and no salt has been indicated at this position by seismic surveys, the evidence reported from the northern Gulf of Mexico (Manheim and Bischoff, 1969), and confirmed in Holes 1 and 2, strongly suggests that the salinity gradient is caused by diffusion from a salt mass at depth.

Accepting previous arguments that mainly salt diffusion rather than bulk fluid movements are causing the salinity gradients, it is possible to determine a rough idea of the salt contribution from the presumed mass at depth by subtracting the ionic composition of sea water from the composition of the deepest pore-water sample. This computation indicates that the salt increment is depleted 10-fold with respect to magnesium in sea salt, depleted 2-fold with respect to potassium, but enriched more than 4-fold with respect to calcium. These figures do not supply more than a qualitative measure of the composition of evaporite minerals being 


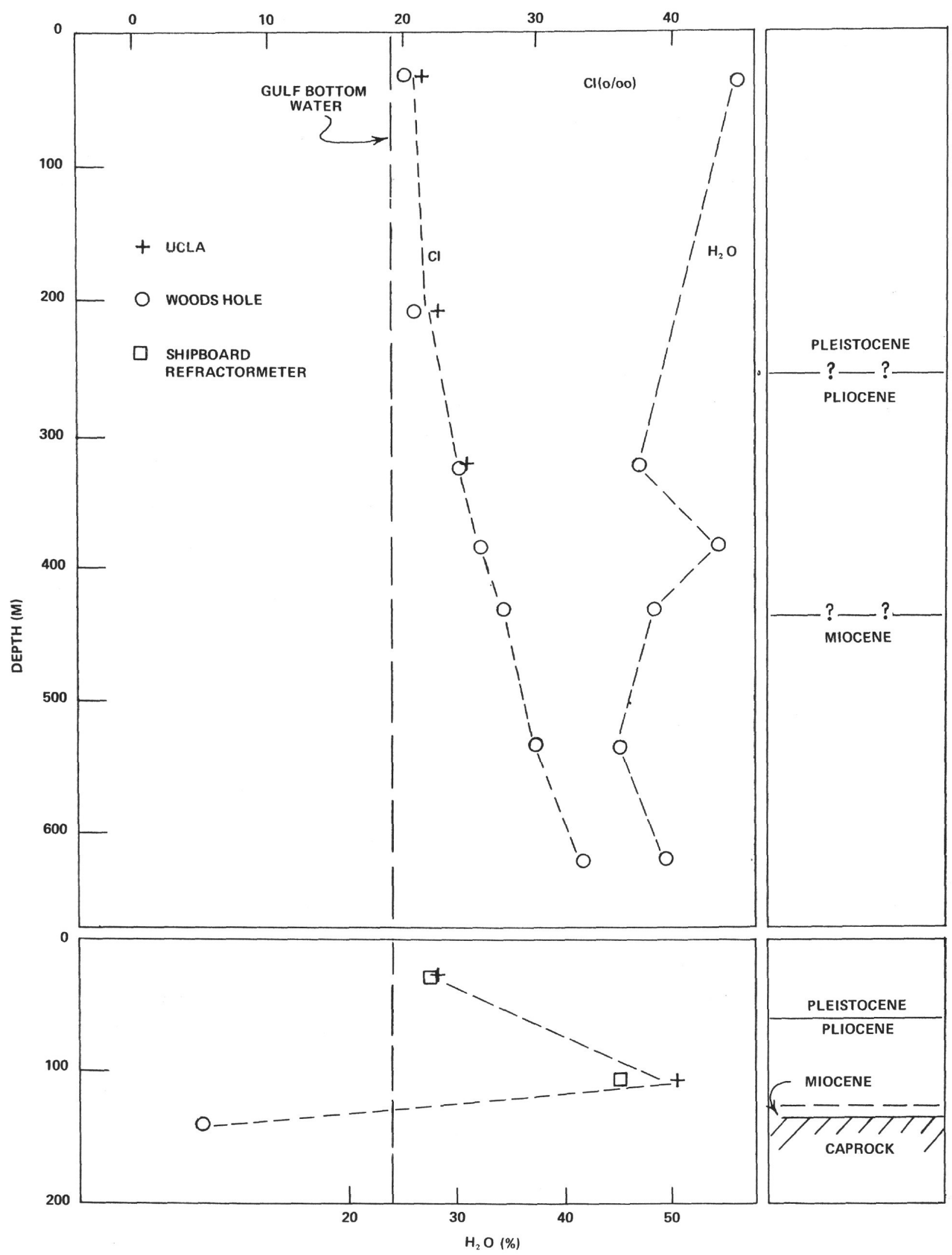

Figure 1. Chlorinity and water content in pore waters, Holes 2 and 3. Refractometer data have been converted to chlorinity in Hole 2 by using refractive index-chlorinity relationships in Hole 3. 
leached from a lower salt mass. Magnesium and potassium concentrations would probably be reduced by uptake on clay minerals in the course of their long migration through sediments. Sulfate that arose through leaching of gypsum or anhydrite would be largely reduced by bacteria, some calcium might be precipitated as a carbonate, and ionic ratios would be modified by the different mobilities (diffusion coefficients of the ions) and differential solution rates of their parent minerals. Significant chromatographic or differential salt sieving effects were not found, however, in previous studies of salt gradients over salt plugs (Manheim and Bischoff, 1969).

Examination of the ionic ratios also shows that sodium to chloride ratios are decreasing in the deepest samples; increasing amounts of calcium are evidently associated with chloride. In the uppermost sample, least affected by diffusing salt, depletions of potassium and magnesium with respect to sea water agree with relationships found throughout Hole 1 and in sediments in the Gulf of Mexico that are not associated with salt diapirs. Alkalinities are generally high, though they decrease toward the more concentrated brines with depth. The increases in bicarbonate alkalinity are probably related, as previously noted (Murray and Irvine, 1893; Shishkina, 1964, and publications cited therein) to reduction of sulfate with corresponding oxidation of organic matter.

\section{Holes 4, 5, 6, and 7 (Bahama - Bermuda Region)}

As found in previous studies from the Guadalupe Mohole (Rittenberg et al., 1963) salinity variations in samples from the open ocean were small, although an approximately 2 per cent increase in chlorinity and salinity within a depth range of about 100 meters in Holes 4 and 5 may be real. The combination of analytical error and especially the inevitable possibilities for minor evaporation during sampling and handling of the sediment render total salinity variations in this range hard to interpret.

Little evidence of sulfate reduction or corresponding increases in bicarbonate alkalinity was noted in Holes 4,5 , and 7 . Moderate reduction was found irregularly in Hole 6. However, the sampling is far too scanty to allow these results to characterize the entire sediment stratum.

Unlike the Gulf of Mexico pore waters in Hole 1 and the top of Hole 3, pore waters from the open ocean holes had a net excess of potassium. Such excesses may be coming from decomposition of volcanic ash or weathering of other silicate rock particles. These processes may be significant as major sources for potassium in the oceans (Mangelsdorf, Wilson and Daniel, 1969). Magnesium concentrations are equal to or less than those in sea water, in agreement with previous observations made from piston core materials (Shishkina, 1964; Siever et al., 1965, and papers cited in these publications).

\section{Water Content - Porosity}

The sampling available for the present work is far too sparse to allow any conclusions about compaction phenomena and modes of loss of pore fluids from the sediment columns. Surprisingly, however, the lowest water contents, from 32 to 40 per cent, occur in the very fine clayey sediments in Hole 1, Gulf of Mexico, whereas biogenic oozes, which are made up of masses of highly porous skeletal fragments contain amounts of water as high as 79 per cent. The highest water content, 84 per cent, was obtained in near-surface brown muds from Hole 7 . There is no clear evidence, except in very near surface sediments, of systematic losses of water content with depth in the oceanic sediments.

We should like to point out that the samples on which these measurements have been made were taken from inner portions of cores. Previous ocean drilling (1965 JOIDES drill holes off Florida) and current experience with the wireline technique indicates that a watery outer layer may be formed around some cores of plastic sediments which is really an artifact of the drilling procedure. This effect may therefore prejudice porosity measurements on whole cores.

\section{REFERENCES}

Behrens, E. W., 1965. Use of the Goldberg refractometer as a salinometer for biological and geological field work. J. Marine Res. 23, 165.

Kaplan, I. R., and Presley, Robert, 1969. Chapter 21, this report.

Mangelsdorf, P. C., Wilson, R. S., and Daniell, Allen, 1969. Potassium enrichments in interstitial waters of recent marine sediments. Subm. for publication.

Manheim, F. T., 1966. A hydraulic squeezer for obtaining interstitial water from consolidated and unconsolidated sediments. U. S. Geol. Surv. Prof. Paper 550-C, 256.

Manheim, F. T., and Bischoff, J. L., (in press) 1969 Geochemistry of pore waters from Shell Oil Co. drill holes on the continental slope of the northern Gulf of Mexico. In Geochemistry of subsurface brines (Symposium), Chemical Geology. E. E. Angino and G. K. Billings (Eds.).

Mehu, Annich, and Johannin-Gilles, Andree, 1968. Variation de l'indice de refraction de l'eau de mer etalon de Copenhague et de ses dilutions en fonction de la longuer l'onde, de al temperature et de la chlorinite. Cahiers oceanographiques. $20,803$.

Murray, John, and Irvine, Robert, 1893. On the chemical changes which take place in the composition of the sea water associated with blue muds of the floor of the ocean. Trans. Roy. Soc. Edinburgh. 37,481 . 
Rittenberg, S. C., Emery, K. O., Hulsemann, Jobst, Degens, E. T., Fay, R. C., Renter, J. M., Grady, J. E., Richardson, S. H., and Bray, E. E., 1963. Biogeochemistry of sediments in experimental Mohole, J. Sediment Petrol. 33, 140.

Shishkina, O. V., 1954. Metodika opredeleniya sul'fat iona $\mathrm{v}$ morskikh vode (Determination of sulfate ion in sea water). Tr. Okeanologii Inst., Akad. Nauk, SSSR. 8, 253.

Shishkina, O. V., 1964. Chemical composition of pore solutions in oceanic sediments. Geochemistry International. 1, 522.

Siever, Raymond, Beck, K. C., and Berner, R. A., 1965. Composition of interstitial waters of modern sediments. J. Geol. 73, 39. 
TABLE 1a

Major Constituents in Pore Water, Reported in $\mathrm{g} / \mathrm{kg}(\% \circ)$

(Total Water is in Per Cent of Original Bulk Weight)

\begin{tabular}{|c|c|c|c|c|c|c|c|c|c|c|c|c|c|}
\hline Sample designation & $\begin{array}{l}\text { Depth Below } \\
\text { Sea Floor }(m)\end{array}$ & Age & Description & $\begin{array}{l}\text { Total } \\
\text { Water }\end{array}$ & $\mathrm{Na}$ & $\mathrm{K}$ & $\mathrm{Ca}$ & $\mathrm{Mg}$ & $\mathrm{Cl}$ & $\mathrm{SO}_{4}$ & $\mathrm{HCO}_{3}{ }^{\mathrm{a}}$ & Sum & Salinity \\
\hline \multicolumn{14}{|c|}{ Hole $1\left(25^{\circ} 51.5^{\prime} \mathrm{N}, 92^{\circ} 11.0^{\prime} \mathrm{W}\right.$, water depth $2827 \mathrm{~m}$, Sigsbee Scarp, Gulf of Mexico $) \mathrm{Cl}$ bottom water $=19.3$} \\
\hline $2-3(117-122)$ & 308 & Pleistocene & Silty mudstone & 40.4 & 10.3 & 0.23 & 0.42 & 1.08 & 18.7 & 0.66 & (1.3) & 32.7 & 31 \\
\hline $7-4(143-150)$ & 704 & Pleistocene & Calcareous mudstone & 32.7 & 11.7 & 0.30 & 0.38 & 1.23 & 20.6 & 2.48 & $(0.1)$ & 36.8 & 37.5 \\
\hline $9-5(145-150)$ & 761 & Pleistocene & Calcareous mudstone & 39.5 & 11.3 & 0.24 & 0.38 & 1.23 & 20.4 & $\mathrm{c}$ & - & $\cdot$ & 37.0 \\
\hline \multicolumn{14}{|c|}{ Hole $2\left(23^{\circ} 27.3^{\prime} \mathrm{N}, 92^{\circ} 35.2^{\prime} \mathrm{W}\right.$, water depth $3572 \mathrm{~m}$, Challenger Knoll, Gulf of Mexico $) \mathrm{Cl}$ bottom water $=19.2$} \\
\hline 5-2 (top \& bot.) & 140 & Miocene-Jurassic & Cap rock & 29.5 & 2.5 & 0.10 & 1.7 & 0.19 & 4.8 & 2.52 & (1.4) & 13.3 & $15.5-18$ \\
\hline \multicolumn{14}{|c|}{ Hole $3\left(23^{\circ} 01.8^{\prime} \mathrm{N}, 92^{\circ} 2.6^{\prime} \mathrm{W}\right.$, water depth $3746 \mathrm{~m}$, abyssal plain Gulf of Mexico $) \mathrm{Cl}$ bottom water $=19.2$} \\
\hline $1-2 \quad(45-50)$ & 34 & Pleistocene & Calcareous silt, clay & 56.1 & 11.0 & 0.26 & 0.48 & 1.05 & 20.0 & 0.58 & (1.2) & 34.6 & 33 \\
\hline $4-1 \quad(29-33)$ & 209 & Pleistocene & Coccolith ooze, clay & $\cdot$ & 12.0 & 0.46 & 0.50 & 0.90 & 21.2 & 0.93 & (1.0) & 37.0 & 34 \\
\hline $5-2 \quad(4-7)$ & 323 & Pliocene & Coccolith ooze, clay & 47.3 & 13.6 & 0.58 & 0.48 & 1.08 & 24.2 & 0.61 & (1.5) & 42.0 & 38 \\
\hline $7-1 \quad(13-21)$ & 382 & Pliocene & Coccolith ooze, clay & 54.1 & 14.2 & 0.60 & 0.55 & 1.08 & 25.8 & - & . & - & 44 \\
\hline $8-3 \quad(10-18)$ & 435 & Pliocene & Coccolith ooze, clay & 48.3 & 15.5 & 0.54 & 0.53 & 1.06 & 27.5 & 0.70 & $(0.7)$ & 46.6 & 44.5 \\
\hline $9-2 \quad(8-16)$ & 535 & Miocene & $\begin{array}{l}\text { Calcareous mudstone, } \\
\text { ash layers }\end{array}$ & 45.3 & 15.7 & 0.53 & 1.00 & 1.28 & 29.5 & 0.57 & $(0.6)$ & 49.2 & 49.5 \\
\hline $\begin{array}{rr} & (4-12) \\
10-2 \quad(44-50)\end{array}$ & 619 & Miocene & Calcareous mudstone & 48.7 & 17.0 & 0.61 & 1.60 & 1.36 & 33.3 & 0.38 & $(0.3)$ & 54.6 & 55 \\
\hline \multicolumn{14}{|c|}{ Hole $4\left(24^{\circ} 28.7^{\prime} \mathrm{N}, 73^{\circ} 47.5^{\prime} \mathrm{W}\right.$, water depth $5320 \mathrm{~m}$, E. of Bahama Is. $) \mathrm{Cl}$ bottom water $=19.3$} \\
\hline $14 \quad(0-4)$ & 6 & $\begin{array}{l}\text { Pliocene- } \\
\text { Pleistocene }\end{array}$ & Calcarenite & 79.1 & 10.7 & 0.41 & 0.37 & 1.30 & 19.2 & 2.79 & $(0.2)$ & 34.8 & 34 \\
\hline \multicolumn{14}{|c|}{ Hole $4 \mathrm{~A}\left(24^{\circ} 28.7^{\prime} \mathrm{N}, 73^{\circ} 47.5^{\prime} \mathrm{W}\right.$, water depth $5320 \mathrm{~m}$, E. of Bahama Is. $) \mathrm{Cl}$ bottom water $=19.3$} \\
\hline $2-1(117-121)$ & 117 & $\begin{array}{l}\text { Cretaceous } \\
\text { (Cenomanian) }\end{array}$ & Coccolith ooze & 42.7 & 11.0 & 0.68 & 0.58 & 1.34 & 19.7 & 2.60 & $(0.1)$ & 37.0 & $38,36.5^{\mathrm{b}}$ \\
\hline \multicolumn{14}{|c|}{ Hole $5\left(24^{\circ} 43.6^{\prime} \mathrm{N}, 73^{\circ} 38.5^{\prime} \mathrm{W}\right.$, water depth $5361 \mathrm{~m}$, E. of Bahama Is. $) \mathrm{Cl}$ bottom water $=19.3$} \\
\hline $1-2 \quad(40-45)$ & 5 & Miocene (?) & Calcareous mud & 73.4 & 10.7 & 0.47 & 0.55 & 1.26 & 19.5 & 2.67 & $(0.2)$ & 35.3 & \\
\hline $2-1 \quad(90-95)$ & 38 & Cretaceous & Buff chalk & 58.2 & 11.6 & 0.56 & 0.57 & 1.32 & 20.2 & 2.60 & $(0.1)$ & 37.0 & $36,37^{\circ}$ \\
\hline
\end{tabular}


TABLE 1a-Continued

Hole $6\left(30^{\circ} 50.4^{\prime} \mathrm{N}, 67^{\circ} 38.9^{\prime} \mathrm{W}\right.$, water depth $5125 \mathrm{~m}$, Bermuda Rise $)$ Cl bottom water $=19.3$

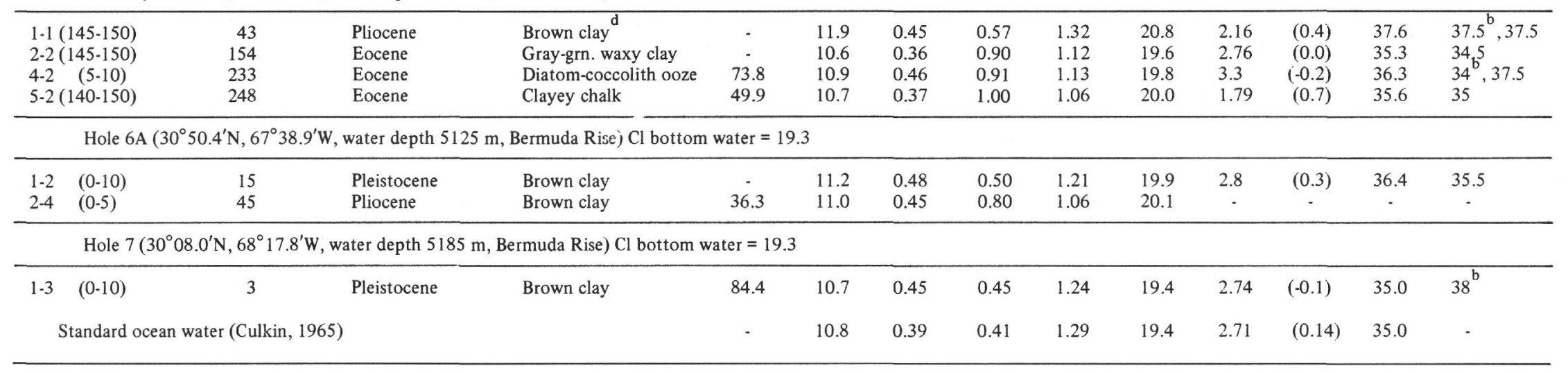

${ }^{\mathrm{a}}$ Excess of cations over anions calculated as $\mathrm{HCO}_{3}$-alkalinity which was not directly determined. Values from -0.2 to 0.3 represent mainly analytical scatter, small $\mathrm{HCO}_{3}-$ content (similar to oceanic values of about 0.1 ) and properly balanced ions. These values give a rough guide to bicarbonate concentration in samplos in thest post-squeezing state in the

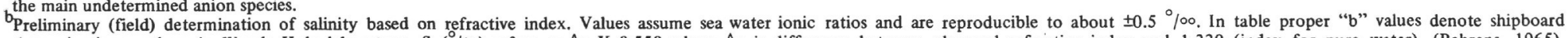
determinations; others in Woods Hole laboratory. S $(\% \circ)$ refrac. $=\Delta n X 0.550$ where $\Delta n$ is difference between observed refractive index and 1.330 (index for pure water). (Behrens, 1965). Insufficient sample for $\mathrm{SO}_{4}$ determination.

dSample possibly affected by evaporation prior to squeezing. 
TABLE 1 b

Preliminary Deuterium Values $(\delta D)$ with Reference to Standard Mean Ocean Water (SMOW) in Per Cent, and Selected Minor Constituents (in ppm).

\begin{tabular}{|c|c|c|c|c|c|c|}
\hline Hole & Core & Section & $\mathrm{D}(\%)$ & $\mathrm{Sr}$ & $\mathrm{Ba}$ & B \\
\hline 1 & 2 & 3 & +0.12 & 15.0 & 1.8 & 5.0 \\
\hline 1 & 7 & 4 & - & 12.0 & 0.4 & 9.0 \\
\hline 1 & 9 & 5 & - & 16.0 & 3.0 & 6.0 \\
\hline 2 & 5 & 2 & +1.88 & 4.0 & $<0.2$ & 8.0 \\
\hline 3 & 1 & 2 & +0.84 & 13.0 & 0.2 & 12.0 \\
\hline 3 & 4 & 2 & - & 10.0 & 1.1 & 8.0 \\
\hline 3 & 5 & 2 & +0.22 & 11.0 & 1.5 & 2.0 \\
\hline 3 & 7 & 1 & - & 14.0 & 2.3 & 5.0 \\
\hline 3 & 8 & 3 & - & 101.0 & 1.6 & 5.0 \\
\hline 3 & 9 & 2 & - & 125.0 & 2.2 & 3.0 \\
\hline 3 & 10 & 2 & -0.67 & 139.0 & 7.0 & $<2.0$ \\
\hline 4 & 1 & 4 & -0.16 & 9.0 & $<0.08$ & 3.0 \\
\hline $4 \mathrm{~A}$ & 2 & 1 & +0.02 & 35.0 & 0.2 & $<2.0$ \\
\hline 5 & 1 & 2 & +0.12 & 9.5 & 0.09 & 4.5 \\
\hline 5 & 2 & 1 & +0.45 & 14.0 & $<0.10$ & 6.0 \\
\hline 6 & 2 & 2 & - & 21.0 & 0.1 & 3.0 \\
\hline 6 & 4 & 2 & -0.32 & 31.0 & 0.2 & 1.3 \\
\hline 6 & 5 & 2 & -0.17 & 30.0 & $<0.08$ & 1.4 \\
\hline $6 \mathrm{~A}$ & 1 & 2 & - & 11.0 & 0.2 & 6.0 \\
\hline $6 \mathrm{~A}$ & 1 & 1 & - & 14.0 & 0.1 & 5.0 \\
\hline $6 \mathrm{~A}$ & 2 & 4 & - & 4.0 & $<0.08$ & 4.5 \\
\hline 7 & 1 & 3 & +0.30 & 7.8 & $<0.08$ & 4.8 \\
\hline
\end{tabular}

